Jurnal Ilmu dan Teknologi Kesehatan

Vol 9, No 1, Sept 2021

ISSN: 2338-9095 (Print)

ISSN: 2338-9109 (online)

\title{
How Do The Community Health Nurses' Experience in The Strategies of Non-Communicable Disease (NCD) Promotion and Prevention?
}

\author{
Rizkiyani Istifada ${ }^{1^{*}}$, Etty Rekawati ${ }^{2}$, Wiwin Wiarsih ${ }^{2}$ \\ ${ }^{1}$ Nursing Department Universitas Muhammadiyah Tangerang, Indonesia \\ ${ }^{2}$ Nursing Faculty Universitas Indonesia, Indonesia \\ *Email: rizkiyani.istifada@gmail.com
}

\section{Article history}

Posted, Mar 12 $2^{\text {th }}, 2021$

Reviewed, Jul 9 ${ }^{\text {th }}, 2021$

Received, Aug $24^{\text {th }}, 2021$

\begin{abstract}
Nurses have an important task in the strategy of intervention to reduce of NonCommunicable Diseases (NCD)' incidence. Community health nurses have tried to control the problem of NCD. However, the incidence of NCD has not decreased as expected. The promotion and prevention of non-communicable diseases are one of the efforts to control PTM. This study aims to explore the experience of nurses in implementing the strategies of NCD' promotive and preventive. This study used a qualitative descriptive phenomenological design. A total of 16 community health nurses were selected using purposive sampling. The inclusion criteria of this study were (1) nurses who served at the community health center for a minimum of 6 months, (2) performed individual health services in the community health center and carried out family visits and services in the community. The data were analyzed using Colaizzi's approach. This research was approved by the Committee of Ethics in the Faculty of Nursing, Universitas Indonesia. This study resulted in five strategies of nurses implementing to NCD' promotion and prevention, include (1) health education, (2) partnership with community health workers, (3) coordination, (4) stand with the community, (5) monitoring the change of behavior in the community. Nurses' experience of NCD's promotion and prevention in the community health center still needs improvement to achieve holistic and comprehensive health services. Nurses should be attention to the preparation of themselves before implementing the promotion and prevention, such as preparation of the topic, communication with colleagues and communities, and doing a partnership with multisectoral.
\end{abstract}

Keywords: community health center; non-communicable disease; nurses; preventive; promotive

\footnotetext{
ABSTRAK

Perawat memiliki peranan penting dalam strategi intervensi untuk menurunkan kejadian Penyakit Tidak Menular (PTM). Perawat kesehatan masyarakat sebagai garda terdepan telah berupaya untuk mengendalikan masalah PTM. Namun, angka kejadian PTM masih belum mengalami penurunan yang diharapkan. Promosi dan pencegahan penyakit tidak menular menjadi salah satu upaya dalam mengendalikan PTM. Penelitian ini bertujuan untuk mengetahui pengalaman perawat dalam menerapkan strategi promotif dan preventif PTM.
} 
Penelitian ini menggunakan studi kualitatif-deskriptif fenomenologi. Partisipan sejumlah 16 perawat kesehatan masyarakat dipilih dengan menggunakan purposive sampling. Kriteria inklusi penelitian ini adalah perawat yang bertugas di puskesmas minimal 6 bulan, melakukan layanan kesehatan perorangan di dalam puskesmas, serta melakukan kunjungan keluarga dan layanan di komunitas. Analisis data menggunakan pendekatan Colaizzi. Hasil penelitian menunjukkan lima strategi yang diterapkan perawat dalam upaya promosi dan pencegahan PTM, yaitu (1) penyuluhan kesehatan, (2) kerja sama dengan kader, (3) koordinasi, (4) berpihak dengan masyarakat, (5) mengawasi perkembangan masyarakat terhadap perubahan perilaku. Pengalaman perawat dalam melakukan promosi dan pencegahan PTM di puskesmas masih perlu ditingkatkan untuk mencapai pelayanan kesehatan yang holistik dan komprehensif. Perawat sebaiknya memperhatikan persiapan diri sebelum melaksanakan promosi kesehatan dan pencegahan, seperti persiapan topik, membangun komunikasi dengan rekan kerja dan masyarakat, serta melakukan kemitraan dengan multisektoral.

Kata Kunci: puskesmas; penyakit tidak menular; perawat; preventif; promotif

\section{INTRODUCTION}

Non-communicable diseases (NCD) was one of the causes of death in developing countries (Khetan et al., 2017). A report by the World Health Organization states that NCD caused 40 million deaths globally (WHO, 2017b). The death of NCD was caused by four major diseases, such as $45 \%$ from cardiovascular disease, $22 \%$ from cancer, $10 \%$ from acute respiratory disease, and $4 \%$ from diabetes mellitus (WHO, 2017a). Southeast Asia was significantly in mortality by NCD for twelve years, from 6.7 million deaths to 8.5 million deaths. NCD causes $42 \%$ of deaths in populations before 70 years. The Southeast Asia region showed the highest proportion of deaths (48\%) from NCD in the population under the age of 70 years. This condition can be interpreted that NCD suffered by adults and the elderly. A person aged 30 years had a $19 \%$ chance of dying before 70 years (WHO, 2014).

A report by Basic Health Research 2018 (Riskesdas) showed that NCD was still a severe problem of health, including Indonesia; $39.6 \%$ hypertension, $11.4 \%$ strokes, $1.6 \%$ heart disease, $0.48 \%$ chronic kidney disease, $8.86 \%$ joint disease, $2.8 \%$ asthma, $1.3 \%$ diabetes mellitus and $1.41 \%$ cancer (Kementerian Kesehatan RI, 2018). Cardiovascular disease, joint disease, and asthma had a higher proportion than the national prevalence, while diabetes mellitus and cancer were below the national prevalence. However, if the result was compared with The Report of Basic Health Research 2013, the proportion of cancer increases from $1 \%$ to $>1 \%$ in West 
Java (Kementerian Kesehatan RI, 2018). This condition showed that noncommunicable diseases were still a priority problem to be solved immediately in West Java.

Community health nurses were one of the health workers at the forefront of public health services (Roden et al., 2016). Community health nurses in Indonesia were known as primary health nurses based on the concept of nursing center (Kementerian Kesehatan RI, 2006; Kementerian Kesehatan RI, 2014). Nurses had a responsibility to improve the healthy behavior of the community through promotive and preventive efforts (Kementerian Kesehatan RI, 2006). Most nurses agreed that promoting promotive and preventive was the critical value in their work (DeCola et al., 2012; Brobeck et al., 2013). According to the research of Wilhelmsson and Lindberg (2009) and Whitehead (2009) that nurses had an important role in developing and implementing health promotion. Most nurses $(61 \%)$ believe that their professional could influence the positive change in society, especially in providing information about NCD prevention (DeCola et al., 2012).
The preliminary studies conducted by researchers show that the government has implemented NCD control programs, such as Posbindu. This program should be able to reduce the prevalence of the incidence of NCD. However, the fact is that the percentage of NCD has not reached the expected target. Indicators of the Healthy Living Community Movement Program (GERMAS) have also not shown any improvement compared to the results of Riskesdas in 2013 (Kementerian Kesehatan RI, 2018). Various studies using assessment instruments have shown an increase in public health status when nurses carry out health promotion and disease prevention (Stanik-Hutt et al., 2013). Therefore, the success of promotive and preventive implementation is closely related to the role of nurses. Other studies also show that nurses' perceptions are important in implementing health promotion and NCD prevention efforts (Luquis and Paz, 2015). Based on these phenomena, the researcher wants to explore the perceptions of nurses' experiences in their strategies for promoting and preventing NCD with a qualitative study design.

\section{METHOD}

This research used a qualitative study with a descriptive phenomenological approach. 
The implementation of NCD's promotion and prevention by nurses was a very complex phenomenon in Indonesia. The complex problems were part of the characteristics that require a qualitative approach as a method of resolution (Creswell, 2007). This study involved 11 community health centers in Depok City, with participants adjusting to data saturation, i.e. 16 nurses. The inclusion criteria of participants included (1) working in a primary health center for at least six months, (2) making individual health efforts and conducting family visits and/or doing services to community health efforts. Participant selection uses a purposive sampling technique with selecting samples chosen by the study's objectives (Streubert and Carpenter, 2011). The validity and reliability involved three nurses in community health centers. The valid criteria included; ability researcher to interviews got quality recordings, and record during interviews.

The data collection method used a semistructured in-depth interview and openended questions to explore the nurses' experience (Table 1). The interviews with each participant lasted 30-60 minutes and were recorded by a voice recorder.

\section{Table 1. Question Script}

- Please explain to me how do you implement NCD' promotive and preventive in your community health center?

- How do you implement the planning, monitoring, and evaluation of NCD' promotive and preventive?

Data analysis used the Colaizzi approach. The phases are started from (1) 3-5 times to re-read the transcript, (2) found the important sentence (write the number and line pages), (3) stated the important sentences in the category of themes, (4) make description the result of data analysis, (5) make definition the based structured of phenomena, (6) validation the result of research description to the participant (Shosa, 2017; Streubert and
Carpenter, 2011). The data have been valid with characterized by criteria of credibility, dependability, confirmability, and transferability. The Committee approved this research of Ethics Faculty of Nursing in Universitas Indonesia (No.49/UN2.F12.D/HKP.02.04/2019) date February 6, 2019, respecting the principles of dignity participants. Keep beneficence and non-maleficence of participants, justice 
for all participants, and making agreements after research explanation.

\section{RESULTS AND DISCUSSION}

Table 2 describes the characteristic of nurses as participants in this study. Most of the participants are female, and their educational background is the diploma of nursing. However, there is still one nurse with an academic background as a senior high school graduate with vocational nursing. The participants are 25-53 years old, with a length of work in the community health center ranging from 3-
30 years. Nurses used five strategies in implementing NCD's promotive and preventive. These include health education, partnership with community health workers, coordination, stand with the community, and monitoring the change of behavior in the community. The results of this study are described in Table 3, which explains the nurse's strategy in implementing NCD's promotive and preventive. A total of 11 community health nurses in implementing NCD's promotive and preventive with health education.

Table 2. Characteristics of Nurses $(n=16)$

\begin{tabular}{ccccc}
\hline $\begin{array}{c}\text { Code of } \\
\text { Participants }\end{array}$ & Gender & Age & Education & $\begin{array}{c}\text { Lengths of } \\
\text { Work }\end{array}$ \\
\cline { 2 - 5 } (years) & (years) & 11 \\
P1 & Male & 35 & Profession of Nursing & 11 \\
P2 & Male & 52 & Diploma of Nursing & 5 \\
P3 & Female & 31 & Diploma of Nursing & 5 \\
P4 & Female & 52 & Diploma of Nursing & 9 \\
P5 & Female & 38 & Diploma of Nursing & 30 \\
P6 & Female & 53 & Senior High School & 4 \\
P7 & Male & 27 & Diploma of Nursing & 5 \\
P8 & Female & 25 & Diploma of Nursing & 3 \\
P9 & Female & 36 & Diploma of Nursing & 9 \\
P10 & Female & 31 & Diploma of Nursing & 3 \\
P11 & Female & 34 & Bachelor of Nursing & 3 \\
P12 & Female & 27 & Diploma of Nursing & 4 \\
P13 & Female & 35 & Diploma of Nursing & 3 \\
P14 & Female & 28 & Diploma of Nursing & 3 \\
P15 & Female & 37 & Diploma of Nursing & 5 \\
P16 & Female & 41 & Profession of Nursing & 3 \\
\hline
\end{tabular}

\section{Strategy [1]: Health Education}

Health education was carried out according to the schedule by each primary health center. Not only health education times were scheduled, but also the nurses have been arranged. The topic of health education is based on problems that were felt by patients when examinations. Nurses are also prepared by ensuring the material 
aspects for themselves with the availability of media.

The timing of health education had varied in each community health center. Three primary health centers carry out health education on scheduled days, usually one time per week.

"I am usually set schedule the time of health education in the building primary health center (community health center) ..." (P1)

Besides, to set the time for health education, one primary health center also divided the schedule of health workers (nurses).

"It was scheduled, we are shifting to deliver health information ... nurses are divided their tasks, like a month twice" (P12)

Five nurses created the planning of the topic before implementing NCD's health education. Three of five nurses prepared the topics of health education based on the examination results and the number of problems that occurred in the community.

"We see from the results of blood pressure examination, and I meet patients ... I am cross-checking from their lifestyle ..." (P16)

The preparation of health education topics adjusted patient problems and sometimes was adjusted to a health day celebration.

\footnotetext{
"it was the Cancer Day on February ... so planning of the topic became situational" (P11)
}

One other participant prepared the topics of health education based on information from community health workers.

"Collaborating with the community health workers ... what material will educate by me to the community this week" (P13)

Four other participants prepared themselves before giving health education. The way that nurses did to prepare themselves includes reading books or articles from the internet.

$$
\begin{gathered}
\text { "I will prepare first ... There's google, there's } \\
\text { a book" }(P 9)
\end{gathered}
$$

Most participants used health education in community health center building to patients. Besides that, health education was done by nurses in The Integrated Development Post (Posbindu) for the target of healthy communities. According to (Astuti, Prasetyowati and Ariyanto, 2016), health messages were delivered to the target of healthy communities in The Integrated Development Post (Posbindu). Health education was also conducted with the target of patients and their families when awaiting examination. The health education strategy is part of the community health nursing concept that aims to give nursing care to vulnerable people with health problems (Nies and McEwen, 2015). 
The Health Profile of Depok City report showed a still higher prevalence of NCD rates in Depok than the other diseases (Dinas Kesehatan Kota Depok, 2018). Vulnerable people need health care from primary health nurses, such as by providing counseling (Allender, Rector and Kristine D. Warner, 2015). This condition explained that the health education strategy was one of the solutions to improve the healthy behavior of the people who had NCD diagnosed. The study results Casey (2007a) also explained that providing health education was one of the health promotion strategies implemented in various ways, one of which was counseling.

The participants explained that the schedule of health education was carried out in the primary health center building when patients and their families waited for medical examinations. The schedule activity of health education was one part of the preparation for implementing health promotion strategies. The research Maijala, Tossavainen and Turunen (2016) showed well prepared with well planning to improve the implementation of promotive and preventive. The strategy that was not carried out with good planning caused having a failure. That condition had an impact on the lack of information received by the community. The results of the study Yuniarti, Shaluhiyah and Widjanarko (2012) showed the things needed by nurses in implementing promotive and preventive, included how to inform health education; how to do training for community health workers; how to make a priority on the based problem; how to assess the community-owned resources; how to provide the media of health promotion, and conduct evaluations. Therefore, the strategies of health education scheduled should be attention to the competencies that nurses have.

Several nurses explained the activities before counseling with the preparation of the speaker and the topic. The result of this research was in line with the study Kemppainen, Tossavainen and Turunen (2013) that described the experience of nurses to literature prepared before the implementation of health promotion. According to several concepts, health promotion practice should be attention to various things with analyzing client needs and arranging plans to methods and supporting media (Allender, Rector and Kristine D. Warner, 2015). Based on this, the implementation of community health nurses in Depok City was by nursing theory. Not many nurses have the awareness to improve their knowledge by 
reading or training. This condition same as the results in several studies that showed the lack of preparation of nurses in carrying out health promotion (Casey, 2007a; Lock et al., 2002; Saarmann, Daugherty, \& Riegel, 2002). Therefore, nurses should improve their ability to search for references for NCD's concept. In research, Maijala, Tossavainen and Turunen (2016) showed the characteristics of professional nurses' success in implementing health promotion, such as studying theories and participating in the pieces of training related to the topics needed.

The results of this study were consistent with the experience of nurses in qualitative research (Casey, 2007b) that applied the performance of topic preparation before implementing health education. The principle of implementing health education is based on identifying problems, the information needed by the community and involves the client in the decision about intervention (Allender, Rector and Kristine D. Warner, 2015). Based on most cases, nurses' experience with topic preparation was in line with the health education concept. The strategy of the topic preparation based on medical cases should be a necessary stage carried out by nurses. This stage was done to improve the sustainability of health education provided for the community. The nurses' experience in this study was also described in the results of the integrative review (Kemppainen, Tossavainen and Turunen, 2013) that nurses should have skill in the implementation of health promotion that focuses on the client/community needs. 


\section{Table 3. The Strategies of Nurses in Implementing about NCD's Promotive and Preventive}

\begin{tabular}{|c|c|c|c|}
\hline Theme & Definition & Category & Descriptor \\
\hline \multirow[t]{4}{*}{ Health education } & \multirow[t]{4}{*}{$\begin{array}{l}\text { Nurses provided } \\
\text { health information } \\
\text { to the community }\end{array}$} & $\begin{array}{l}\text { Scheduled health } \\
\text { education }\end{array}$ & $\begin{array}{l}\text { "I am usually set schedule the } \\
\text { time of health education in the } \\
\text { building primary health center } \\
\text { (community health center) ..." } \\
(P 1)\end{array}$ \\
\hline & & $\begin{array}{l}\text { Preparation of nurses in } \\
\text { providing material }\end{array}$ & $\begin{array}{l}\text { "I will prepare first ... There's } \\
\text { google, there's a book "(P9) }\end{array}$ \\
\hline & & & "Collaborating with the \\
\hline & & $\begin{array}{l}\text { Material of the topic } \\
\text { preparation }\end{array}$ & $\begin{array}{l}\text { community health workers ... } \\
\text { what material will educate by } \\
\text { me to the community this week" } \\
(P 13)\end{array}$ \\
\hline \multirow[t]{3}{*}{$\begin{array}{l}\text { Partnership with } \\
\text { community health } \\
\text { workers (CHW) }\end{array}$} & \multirow{3}{*}{$\begin{array}{l}\text { Activities by } \\
\text { nurses and } \\
\text { community health } \\
\text { workers to achieve } \\
\text { common goals }\end{array}$} & Follow-up the report; & $\begin{array}{l}\text { "Get information from } \mathrm{CHW} . . \\
\text { then I make appointments with } \\
\mathrm{CHW} \text { (P5) }\end{array}$ \\
\hline & & Share tasks & $\begin{array}{l}\text { "The elderly themselves ... } \\
\text { accompanied by their } \mathrm{CHW} . .\end{array}$ \\
\hline & & & $\begin{array}{l}\text { Later, the CHW will give } \\
\text { information to their (elderly) } \\
\text { families" (P8); }\end{array}$ \\
\hline \multirow[t]{3}{*}{ Coordination } & \multirow[t]{3}{*}{$\begin{array}{l}\text { Activities carried } \\
\text { out by nurses in the } \\
\text { form of partnership } \\
\text { and } \\
\text { communication in } \\
\text { controlling NCD } \\
\text { programs. }\end{array}$} & Intersectoral; & $\begin{array}{l}\text { "Report to the head of } \\
\text { community health center, when } \\
\text { there will be a village council, } \\
\text { the head of community health } \\
\text { center will tell the head of } \\
\text { district" (P10) }\end{array}$ \\
\hline & & Inter program; & $\begin{array}{l}\text { "When I found the case in the } \\
\text { field, I consulted by WhatsApp } \\
\text { or face to face with the doctor" } \\
(P 5)\end{array}$ \\
\hline & & $\begin{array}{l}\text { Collaboration with clients } \\
\text { and their families }\end{array}$ & $\begin{array}{l}\text { "I involve (re: family). It is } \\
\text { impossible to me visit the family } \\
\text { continuously" (P9); }\end{array}$ \\
\hline \multirow[t]{3}{*}{$\begin{array}{l}\text { Stand with the } \\
\text { community }\end{array}$} & \multirow[t]{3}{*}{$\begin{array}{l}\text { Do good or be on } \\
\text { the side of society }\end{array}$} & $\begin{array}{l}\text { Showing a positive } \\
\text { attitude; }\end{array}$ & $\begin{array}{l}\text { "We listen more, after that we } \\
\text { give suggestion" (P16) }\end{array}$ \\
\hline & & $\begin{array}{l}\text { Using community } \\
\text { language; }\end{array}$ & $\begin{array}{l}\text { "Not using the medical word, } \\
\text { but who can understand the } \\
\text { community..." (P7) }\end{array}$ \\
\hline & & Give a warning & $\begin{array}{l}\text { "The community didn't do the } \\
\text { diet, exercise ... it's useless } \\
\text { and failed for the medical } \\
\text { therapy if you always } \\
\text { consumption the medicine } \\
\text { maybe your kidney would be } \\
\text { damaged" (P3) }\end{array}$ \\
\hline \multirow[t]{2}{*}{$\begin{array}{l}\text { Monitoring the } \\
\text { change of behavior } \\
\text { in the community }\end{array}$} & \multirow[t]{2}{*}{$\begin{array}{l}\text { Nurses carry out } \\
\text { supervision to find } \\
\text { out behavior } \\
\text { changes in public } \\
\text { health. }\end{array}$} & $\begin{array}{l}\text { Checking the results of } \\
\text { the visit at that time }\end{array}$ & $\begin{array}{l}\text { "I usually monitor what } \\
\text { changes have been made by } \\
\text { patients in the next visit. If the } \\
\text { result examination is still high, I } \\
\text { give health education" (P4) }\end{array}$ \\
\hline & & $\begin{array}{l}\text { Checking nurse } \\
\text { documentation }\end{array}$ & $\begin{array}{l}\text { "There is a kind of book } \\
\text { present, and there is the note of } \\
\text { patient blood pressure every } \\
\text { month" (P6) }\end{array}$ \\
\hline
\end{tabular}




\begin{tabular}{|c|c|c|c|}
\hline Theme & Definition & Category & Descriptor \\
\hline & & $\begin{array}{l}\text { Ask the community at the } \\
\text { time. }\end{array}$ & $\begin{array}{l}\text { "I ask them about what we } \\
\text { explained the previous meeting } \\
\ldots \text { if he didn't remember, I } \\
\text { assume he didn't do what I } \\
\text { explained" }(P 7)\end{array}$ \\
\hline
\end{tabular}

\section{Strategy [2]: Partnership with Community Health Workers}

Collaboration with community health workers was carried out as a strategy in implementing NCD' promotive and preventive. Twelve nurses believed community health workers as the mediator between nurses and the community. In coordinating, community health workers convey the case finding of health problems, then the reporting from community health workers are followed up by nurses.

"There are reports from community health workers regarding case finding, and we will visit them" $(P 1)$

Nurses also collaborate by sharing tasks with community health workers. The tasks were implementing the Integrated Development Post (Posbindu) and helped nurses monitor the community with vulnerable or had health risks. Community health workers have been trained to measure the examination of LILA, blood pressure, and blood sugar.

"Community health workers only measure the examination of LILA, height and weight body" (P11)
Three nurses divided the tasks of community health workers to control the community who needed assistance.

"The community health workers... reminds ... for the time to check blood sugar" (P15)

One nurse assigned community health workers to help the community with health problems.

"Collaboration of community health workers to control in the community health center, refer patients ... in here (re: primary health center/community health center)" (P16)

The collaboration with community health workers becomes more optimal if coordination is created well. In this strategy, nurses coordinate with community health workers and multisectoral stakeholders, cross-program, and build communication with clients and families. One of three nurses who conducted multisectoral coordination rarely coordinates directly with the stakeholder. More ideas were conveyed to the Head of the Primary Health Center (Community Health Center) to be continued in multisectoral meetings.

"Report to the head of the community health center. There will be a village meeting (re: musrembang) later, the head of community 
health center will tell the local government later" (P10)

The results of this study indicate that partnership with community health workers is a strategy for health promotion and prevention. Nurses need coordination with the community by the principle of community health center (Paterson, Duffett-Leger and Cruttenden, 2009). The form of coordination allowed to share the tasks with community health workers based on their authority. This research was related to various studies that the coordination between nurses and community health workers could improve NCD effectiveness in the community (Istifada and Rekawati, 2019; Suparto, Sunjaya and Susanti, 2015; Neupane et al., 2017). Nurses in this study explained the involvement of community health workers in implementing NCD' promotive and preventive based on the report from community health workers about the community health problem. Nurses explained that community health workers had been taught to check blood pressure with digital tension and simple blood sugar. The task of community health workers in the Integrated Development Post includes early detection activities, monitoring of risk factors, and follow-up health status for the community (Astuti, Prasetyowati and Ariyanto, 2016).
The task of community health workers to examine caused nurses to have to do assistance for them. Based on the concept of the guidelines of community health workers, case finding can only be practice with accompaniment by health workers. Community health workers can examine blood pressure, blood sugar, and body mass index (Kementerian Kesehatan RI, 2012). Nurses should assist community health workers in their responsibility and authority to prevent the failure of the result' examination. The involvement and accompaniment of community health workers in implementing NCD promotive and preventive was a part of the community health nursing concept to improve community-based health in The Integrated Development Post (Nies and McEwen, 2015). The social ecology model also explained the community behavior associated with preventing the diseaserelated with organizational, community, and population factors (Edberg, 2013).

\section{Strategy [3]: Coordination}

Two nurses coordinated directly with the government through workshops or meetings that discussed the community problem.

"In the meeting of multisectoral, we discuss with a head of primary health center (community health center) and the local government ... we can deliver health information in there" (P3) 
Most nurses have cross-program coordination (interprofessional). Seven of eight nurses coordinated interprofessional with the doctors or nutritionists. Because most patients who came to the primary health center (community health center) were patient-controlled and needed nutrition services.

"I collaborate with a nutritionist about the diet nutrition of stroke patient, collaborating with doctor related to drugs" (P1)

Another nurse coordinated with the midwife as a responsible person in some areas if the nurse cannot attend the Integrated Development Post (Posbindu). Midwives represent nurses to assist the community who have vulnerabilities.

"I do coordination ... with a midwife as the responsible person of area" (P10)

The other nurses coordinated to involve the clients or their families in health interventions. Six of seven nurses explained that involving clients or their families was important to establish a client and family.

"I have to trust the patient... must cooperate... but if the patient is uncooperative or distrustful, we will certainly guide him."

"I involve (re: family) it is impossible to visit continuously” (P9)
One nurse involved the clients as a health educator to share experiences when they get diagnosed with NCD.

"One of the prolanis members is breast cancer, and she explained herself, based on her experience ..." (P11)

The coordination was done with community health workers. The coordination was carried out with the local government, the cross programs sector, and the clients or families during the treatment process. Nurses' experience in this study was in line with research by Maijala, Tossavainen and Turunen (2016) that nurses needed coordination with multisectoral to achieve the successful implementation of health promotion. This coordination had been shown by collaborating with stakeholders in healthy life planning about tobacco control policies. This process was an effort to improve healthy lives for the community. This result was by research Navarro et al. (2007) that the implementation of health promotion required a partnership between networks, organizations, and communities.

The coordination was applied in collaboration between nurses and other interprofessional (doctors and nutritionists). The study results in Kemppainen et al. (2013) showed that the 
strategies of implementation by nurses in health promotion had been applied by collaborating with the other professional health workers. In the community health center, the role of nurses is independent and collaborative professionals (Naylor and Kurtzman, 2010). In this study, nurses collaborate with other interprofessional about the treatment and lifestyle. This result was consistent with the research (Paterson, Duffett-Leger and Cruttenden, 2009) that nurses needed partnership with other health workers based on consideration of access and resources. The results of this study Kemppainen et al. (2013) and Povlsen and Borup (2011) explained coordination between nurses and families when families should decisions the choice of treatment for the client. Families know the problems of the client and decided what the treatments have been for clients. Another nurse felt trust for the client to decide on the treatment needed. Nurses created therapeutic relationships as a key in implementing health promotion (Casey, 2007a; Svedberg, Jormfeldt and Arvidsson, 2003). The feeling of trust was an important part of making confidence for clients in improving healthy behaviors. It is also by the concept that nurses should involve clients and their families in implementation and evaluation (Berman, Snyder and Frandsen, 2016).

\section{Strategy [4]: Stand with the community}

The other strategy that nurses had applied with a stand to the community. Nurses could be shown by showing a positive attitude, such as speaking with the community language and warning about the effect if the community didn't do the implementation health promotion who been educated by nurses. The positive attitude expression was shown with verbal and non-verbal (body language) by nurses. The delivery of health education was explained by nurses with a positive attitude, giving positive reinforcement, and always greeting.

"... the reward that I gave with says 'you are amazing'..." (P9)

"... our greeting will also bring enthusiasm to the community" (P8)

Body language (non-verbal) is also an important element in expressing to always stand with patients. Those expressions are indicated by patience, well body language, and willingness to listen to the clients' feelings.

"I have to be friendly with patients" (P2)

"I will hold his shoulder, and I smile"(P2)

Five nurses showed a form of partisanship by using community language when delivering health information to the community.

"We use community language when we deliver health information" (P16) 
Five nurses showed their standing with the community by giving warnings about the effects of non-compliance with health intervention. According to participants, this method succeeded in increasing the desire to improve lifestyle.

"... if people are rarely controlled this can be like this (re: show the video about a patient with legs amputated). You want to be like this, legs are amputated ... "(P8)

Most of the participants showed positive attitudes accompanied by a friendly attitude, attention to non-verbal expressions, patience, and open communication with the community. Based on research, Jerdén et al. (2006) explained the implementation of health promotion expressed by being a positive attitude, attentive to non-verbal expressions (body language) and good communication with the community. The results of this study showed using easy language that was understood when informed health education. In this study, when nurses gave health information, it was usually accompanied by discussions with friendly expressions. Consistent with Jerdén et al. (2006) research, nurses should be empathetic, sensitive listeners, and have good interactions with clients during health education. Another attitude is shown by one participant in this study that given a positive appreciation as achievements for the client. Caring by not criticizing the client and giving awards was part of medication (Watson, 2003). A social cognitive theory explained the success of behavior change related to self-confidence from positive responses and affirmations (Stanhope and Lancaster, 2020).

The strategy was by nurses' experience in research Hörnsten et al. (2014) by pressure/warning when delivering health information to the public. In this study, nurses had a strategy by showing a video about the effects of unhealthy behavior that were horrible (for example: showing the fourth stage of wound/amputated legs). According to nurses, this method has succeeded in changing people's mindsets for health behavior. Several studies have shown that warning about signs and symptoms of stroke disease by television, video, and radio which more effective in increasing health promotion (Jurkowski et al., 2010; Worthmann et al., 2013). However, Casey (2007a) showed that an autocratic approach (give a warning) should not be made in this study. Negotiation was the best approach to consider the clients when decided the treatment to improve healthy behaviors (Casey, 2007a). The warning strategy should not be performed to inform health 
promotion because it caused a failure to invite people to change their bad habits.

\section{Strategy [5]: Monitoring the change of behavior in the community}

Another important strategy in implementing health promotion and prevention of NCD is monitoring the change of behavior in the community. The ways that could be done are by looking at the examination results during the next visit, checking the medical records, and asking about an understanding of health information. The nurse saw the medical check-up results and supervised the change of behavior by applying the intervention in the previous visit.

"I usually monitor what changes have been made by patients in the next visit. If the result examination is still high, I give health education" (P4)

The nurse also looked at the client's medical records or recordings in Integrated Development Post (Posbindu).

"There is a kind of book present. There is the note of patient blood pressure every month" (P6)

Some nurses supervised the clients from the patients' responses about their health behavior change- the form of questions and answers conducted about their understanding of health information.

"I ask them about what we explained the previous meeting ... if he didn't remember, I assume he didn't do what I explained" (P7)
Most participants (nurses) only monitored the client, and three methods evaluated only one participant. All nurses have not implemented good evaluation methods.

Another strategy by nurses was applied to monitor the changes in community behavior. Most nurses observe client behavior modification by seeing their medical records before giving health education. The treatment by nurses was the part of the nursing process with identifying health status and evaluating based on the result of examination (Allender, Rector and Kristine D. Warner, 2015). The other strategies are applied by asking about the current condition. The study by Keleher and Parker (2013) showed the first check and recall to the patient before delivered health education. This statement was also explained in the research Jerdén et al. (2006) that nurses saw the medical record to know the changes in patient behavior. This study was by the concept of a previous study. However, the strategies have not been applied by nurses. Therefore, the results of this study could provide an overview of community health nurses in implementing NCD' promotive and preventive. The strategies could be used as an overview about nurses with the implementation of topic preparation before delivering health education to the 
community. The preparation of the topic referred to identifying problems, so nurses adjusted the treatment based on most cases and the community needs. The preparation of learning materials was one of the strategies that nurses must consider, such as reading literature, upgrading information, and training about NCD's topic. This study also resulted in an overview of strategies for nurses in inviting people to change their bad habits. The method that can be used by negotiating. Give alerting or forcing clients was an unfavourable strategy for nurses. Nurses can improve their competence in communicating with the community.

\section{CONCLUSION}

The results of this study indicate that the strategy of implementing is based on previous research. All participants have not applied this strategy. It means that not all nurses have implemented the strategy. Therefore, the results of this study can provide an overview for community nurses so that the implementation of promotional and preventive efforts runs optimally and according to the expected targets.

The strategies that nurses can illustrate implementing topic preparation and selfpreparation (presenters) before providing health education to the public. Topic preparation refers to identifying problems, thus adapting to most cases and the needs of the community. Besides, topic preparation is one of the strategies that nurses must pay attention to, such as reading literature, upgrading information, and attending the training. The study also describes an overview of the strategy for nurses to invite the community to a healthy lifestyle. Nurses also coordinate with colleagues and collaborate with interprofessionals. This coordination is carried out as a form of cooperation to implement programs to improve public health. The method that can be applied as a strategy by negotiating. Giving warnings or forcing clients to choose which interventions to use is a bad strategy for nurses. Another strategy carried out by nurses in implementing health promotion is by monitoring the community through health checks and evaluations. Therefore, nurses can improve their competence in communicating with the community.

\section{ACKNOWLEDGEMENT}

We would like to thank The Department of Health in Depok and all the nurses of the community health centre at Depok who participated in the study. We would also like to thank you for allowing us to 
research the implementation of NCD's promotive and preventive.

\section{REFERENCES}

Allender, J. A., Rector, C. and Kristine D. Warner (2015) Community \& Public Health Nursing: Promoting the Public's Health. USA: Lippincott Williams \& Wilkins.

Astuti, E. D., Prasetyowati, I. and Ariyanto, Y. (2016) 'Gambaran Proses Kegiatan Pos Pembinaan Terpadu Penyakit Tidak Menular di Puskesmas Sempu Kabupaten Banyuwangi (The Description of Activity Process for the Integrated Development Post of NonCommunicable Disease (IDP of NCD) at Sempu Public Health Centre)', Pustaka Kesehatan, 4(1), pp. 160-167.

Berman, A., Snyder, S. and Frandsen, G. (2016) Kozier\&Erb's Fundamentals of Nursing: Concepts, Process, and Practice. England: Pearson.

Brobeck, E. et al. (2013) 'Health Promotion Practice and Its Implementation in Swedish Health Care', International Nursing Review, 60(3), pp. 374-380. doi: https://doi.org/10.1111/inr.12041.

Casey, D. (2007a) 'Nurses' Perceptions, Understanding and Experiences of Health Promotion', Journal of Clinical Nursing, 16(6), pp. 1039-1049. doi: https://doi.org/10.1111/j.13652702.2007.01640.x.

Casey, D. (2007b) 'Using action research to change health-promoting practice', Nursing and Health Sciences, 9(1), pp. 5-13. doi: https://doi.org/10.1111/j.14422018.2007.00297.xx.
Creswell, J. W. (2007) Qualitative inquiry and research design: Choosing among five traditions, Qualitative Health Research. doi: https://doi.org/10.1111/14679299.00177.

DeCola, P. et al. (2012) 'Nurses' potential to lead in non-communicable disease global crisis', International nursing review, 59(3), pp. 321-330. doi: https://doi.org/10.1111/j.14667657.2012.01006.x.

Dinas Kesehatan Kota Depok (2018) Profil Kesehatan Kota Depok Tahun 2017. Depok.

Edberg, M. C. (2013) Essentials of Health Behavior: Social and Behavioral Theory in Public Health. Canada: Jones and Bartlett Publishers.

Hörnsten, ̊. et al. (2014) 'Strategies in Health-Promoting Dialogues - Primary Healthcare Nurses' perspectives - A Qualitative Study', Scandinavian Journal of Caring Sciences, 28(2), pp. 235-244. doi: https://doi.org/10.1111/scs.12045.

Istifada, R. and Rekawati, E. (2019) 'Peran Kader Kesehatan dalam Promosi Pencegahan Komplikasi Hipertensi di Wilayah Perkotaan : Literatur Review', Dunia Keperawatan, 7(1), pp. 28-46.

Jerdén, L. et al. (2006) 'Experiences of Swedish community health nurses working with health promotion and a patient-held health record', Scandinavian Journal of Caring Sciences, 20(4), pp. 448-454. doi: https://doi.org/10.1111/j.14716712.2006.00427.x.

Jurkowski, J. M. et al. (2010) 'Impact of a Multimedia Campaign to Increase Intention to Call 9-1-1 for Stroke Symptoms, Upstate New York, 20062007', Preventing chronic disease, 
$7(2)$, pp. $1-11$.

Keleher, H. and Parker, R. (2013) 'Health Promotion by Primary Care Nurses in Australian General Practice', Collegian, 20(4), pp. 215-221. doi: https://doi.org/10.1016/j.colegn.2012.0 9.001 .

Kementerian Kesehatan RI (2006) Pedoman peyelenggaraan upaya perawatan kesehatan masyarakat di puskesmas: Keputusan Menteri Kesehatan No. 279 tahun 2006. Indonesia: Kementerian Kesehatan RI.

Kementerian Kesehatan RI (2012) Petunjuk Teknis Pos Pembinaan Terpadu Penyakit Tidak Menular (Posbindu PTM), Ditjen Pengendalian Penyakit dan Penyehatan Lingkungan, Kementerian Kesehatan RI. Jakarta: Kementerian Kesehatan Republik Indonesia.

Kementerian Kesehatan RI (2014) Pusat Kesehatan Masyarakat: Peraturan Menteri Kesehatan No. 75 tahun 2014. Indonesia: Kementerian Kesehatan RI.

Kementerian Kesehatan RI (2018) Hasil Utama Riskesdas Tahun 2018. Jakarta.

Kemppainen, V., Tossavainen, K. and Turunen, H. (2013) 'Nurses' roles in health promotion practice: An integrative review', Health Promotion International, 28(4), pp. 490-501. doi: https://doi.org/10.1093/heapro/das034.

Khetan, A. K. et al. (2017) 'The Effectiveness of Community Health Workers for CVD Prevention in LMIC', Global Heart, pp. 233-243.e6. doi:

https://doi.org/10.1016/j.gheart.2016.07 .001 .

Lock, C. A. et al. (2002) 'A Qualitative Study of Nurses' Attitudes and
Practices Regarding Brief Alcohol Intervention in Primary Health Care', Journal of Advanced Nursing, 39(4), pp. 333-342. doi: https://doi.org/10.1046/j.13652648.2002.02294.x.

Luquis, R. R. and Paz, H. L. (2015) 'Attitudes About and Practices of Health Promotion and Prevention Among Primary Care Providers', Health Promotion Practice, 16(5), pp. 745-755. doi: https://doi.org/10.1177/1524839914561 516.

Maijala, V., Tossavainen, K. and Turunen, H. (2016) 'Health promotion practices delivered by primary health care nurses: Elements for success in Finland', Applied Nursing Research, 30, pp. 45-51. doi: https://doi.org/10.1016/j.apnr.2015.11. 002.

Navarro, A. M. et al. (2007) 'Charting the Future of Community Health Promotion: Recommendations From the National Expert Panel on Community Health Promotion', Preventing Chronic Disease, 4(3), pp. $1-7$.

Naylor, M. D. and Kurtzman, E. T. (2010) 'The Role Of Nurse Practitioners In Reinventing Primary Care', Health Affairs, 29(5). doi: https://doi.org/10.1377/hlthaff.2010.04 40.

Neupane, D. et al. (2017) 'Identifying Female Community Health Volunteers' Understanding and Motivations About Blood Pressure Control: A Prerequisite for Developing Community-Based Interventions for Hypertension in Nepal', Global heart, 12(3), pp. 227232.

doi: https://dx.doi.org/10.1016/j.gheart.2016 
.09 .003 .

Nies, M. A. and McEwen, M. (2015) 'Community/Public Health Nursing: Promoting The Health of Populations'. Canada: Elsevier.

Paterson, B. L., Duffett-Leger, L. and Cruttenden, K. (2009) 'Contextual factors influencing the evolution of nurses' roles in a primary health care clinic', Public Health Nursing, 26(5), pp. 421-429. doi: https://doi.org/10.1111/j.15251446.2009.00800.x.

Povlsen, L. and Borup, I. K. (2011) 'Holism in nursing and health promotion: Distinct or related perspectives? - A literature review', Scandinavian Journal of Caring Sciences, 25(4), pp. 798-805. doi: https://doi.org/10.1111/j.14716712.2011.00885.x.

Roden, J. et al. (2016) 'Australian Rural, Remote and Urban Community Nurses' Health Promotion Role and Function', Health promotion international, 31(3), pp. 704-714. doi: https://doi.org/10.1093/heapro/dav018.

Saarmann, L., Daugherty, J. and Riegel, B. (2002) 'Teaching Staff a Brief Cognitive-Behavioral Intervention', Medsurg Nurs, 11(3), p. 144.

Shosa, G. A. (2017) 'Employment of Colaizzi's Strategy in Descriptive Phenomenology: A Reflection of A Researcher', European Scientific Journal, 8(27), pp. 31-43. doi: https://doi.org/10.1038/s41598-01709255-5.

Stanhope, M. and Lancaster, J. (2020) Public Health Nursing: Population Centered Health Care in The Community. 10th Edition. Canada: Elsevier.
Stanik-Hutt, J. et al. (2013) 'The Quality and Effectiveness of Care Provided by Nurse Practitioners', Journal for Nurse Practitioners, 9(8), pp. 492-500.13. doi:

https://doi.org/10.1016/j.nurpra.2013.0 7.004 .

Streubert, H. J. and Carpenter, D. R. (2011) Qualitative Research in Nursing: Advancing The Humanistic Imperative. Philadelphia: Lippincott Williams \& Wilkins.

Suparto, T. A., Sunjaya, D. K. and Susanti, R. D. (2015) 'Masalah-Masalah Program Posbindu Di Desa Dayeuhkolot, Kabupaten Bandung, Jawa Barat', Jurnal Pendidikan Keperawatan Indonesia, 1(1), pp. 1$17 . \quad$ doi: https://doi.org/10.17509/jpki.v1i1.1185

Svedberg, P., Jormfeldt, H. and Arvidsson, B. (2003) 'Patients' Conceptions of How Health Processes Are Promoted in Mental Health Nursing. A Qualitative Study', Journal of psychiatric and mental health nursing, 10(4), pp. 448456.

doi: https://doi.org/10.1046/j.13652850.2003.00633.x.

Watson, J. (2003) 'Love and Caring Ethics of Face and Hand-An Invitation to Return to the Heart and Soul of Nursing and our Deep Humanity', Nursing Administration Quarterly, 27(3), pp. 197-202. doi: https://doi.org/10.1097/00006216200307000-00005.

Whitehead, D. (2009) 'Reconciling the differences between health promotion in nursing and "general" health promotion', International Journal of Nursing Studies, 46(6), pp. 865-874. doi: https://doi.org/10.1016/j.ijnurstu.2008. 12.014 . 
R. Istifada, E. Rekawati, W. Wiarsih, How Do The Community Health Nurses' Experience in The Strategies of Non-Communicable Disease (NCD) Promotion and Prevention?

WHO (2014) Global status report on noncommunicable diseases 2014. Geneva.

WHO (2017a) Non-Communicable Diseases, Progress Monitor 2017. Geneva.

WHO (2017b) Status of The HealthRelated SDGs. Geneva.

Wilhelmsson, S. and Lindberg, M. (2009) 'Health Promotion: Facilitators and Barriers Perceived by District Nurses', International Journal of Nursing Practice, 15(3), pp. 156-163. doi: https://doi.org/10.1111/j.1440-

172X.2009.01740.x.

Worthmann, H. et al. (2013) 'Educational Campaign on Stroke in an Urban
Population in Northern Germany: Influence on Public Stroke Awareness and Knowledge', International Journal of Stroke, 8(5), pp. 286-292. doi: https://doi.org/10.1111/j.17474949.2012.00809.x.

Yuniarti, Y., Shaluhiyah, Z. and Widjanarko, B. (2012) 'Kinerja Petugas Penyuluh Kesehatan Masyarakat dalam Praktek Promosi Kesehatan di Dinas Kesehatan Kabupaten Pati', Jurnal Promosi Kesehatan Indonesia, 7(2), pp. 165173. doi: https://doi.org/10.14710/jpki.7.2.165173. 